\title{
Agnieszka Gondor-Wiercioch
}

(1) https://orcid.org/0000-0002-8849-0942

Instytut Amerykanistyki i Studiów Polonijnych

Uniwersytet Jagielloński

e-mail: agnieszka.gondor-wiercioch@uj.edu.pl

\section{POCIĄG DO PRZYSZłOŚCI - LEKCJA HISTORII Z COLSONEM WHITEHEADEM}

\author{
Train to the Future - History Lesson with Colson Whitehead
}

\begin{abstract}
In my article I am going to focus on the innovating way in which Colson Whitehead presents African-American history in his novel The Underground Railroad. Similarly, to the classical texts exposing erased and buried histories in the U.S. such as written by William Faulkner and Toni Morrison, Whitehead proposes a history lesson for Americans and non-Americans, but instead of producing another historical reconstruction, he uses the technique of multisynchronism combining the past, present and future that constantly interplay in his narrative. The plot that binds all other motives together is that of the Underground Railroad which is simultaneously referring us to the historical organization and a secret vehicle that never stops and thus it is a metaphor for actions undertaken to abolish systemic racism that never ends in the U.S. I would like to argue that apart from the above-mentioned literary strategies Whitehead also created timeless language so different from his literary predecessors like Faulkner and Morrison who often relied on modernist history reconstruction and the use of dialects (including AAVE). In my article I will not only attempt to answer the question if Whitehead's formal achievements are indeed revolutionary, but I will analyse his way of incorporating Black history into fiction, trying to compare his diagnosis of the American society to the conclusions of Faulkner's Light in August and Morrison's Beloved. I will focus particularly on the combination of post-racial prose, speculative realism and afrofuturism.
\end{abstract}

Keywords: afrofuturism, African-American novel, neo-slave narrative, postrace fiction, speculative satire

Kolej podziemna. Czarna krew Ameryki Colsona Whiteheada ${ }^{1}$ jest jedną z nielicznych powieści amerykańskich, które otrzymały zarówno National Book Award, jak i Nagrodę Pulitzera. Należący do czołowych badaczy prozy etnicznej w USA Ramón Saldívar okrzyknął prozaika jednym z najbardziej innowacyjnych pisarzy

C. Whitehead, Kolej podziemna. Czarna krew Ameryki, przeł. R. Lisowski, Albatros, Poznań 2017. 
amerykańskich z nurtu prozy postrasowej (postrace fiction) ${ }^{2}$ już po lekturze jego wcześniejszych powieści, zanim Whitehead zyskał międzynarodowy rozgłos. W niniejszym artykule zamierzam przyjrzeć się Kolei podziemnej, odpowiadając na pytanie o jej nowatorstwo w kontekście dialogu z historią Afroamerykanów. Czy rzeczywiście możemy mówić o rewolucji we współczesnej literaturze etnicznej? Co składa się na wyjątkowość propozycji Whiteheada w stosunku do klasyków literatury amerykańskiej? W tym miejscu zamierzam skrótowo odnieść się do historii Afroamerykanów w powieści modernistycznej Świattość w sierpniu Williama Faulknera ${ }^{3}$ oraz prezentacji tego samego motywu $\mathrm{w}$ prozie $\mathrm{z}$ gatunku neo-slave narrative ${ }^{4}$ Umiłowanej Toni Morrison ${ }^{5}$. Wspólnym mianownikiem mojej analizy będzie lekcja historii, której podejmuje się każdy z autorów i autorek zajmujących się tą problematyką, oraz ewolucja gatunkowa wraz $\mathrm{z}$ towarzyszącymi jej zmianami w wykorzystaniu czasu i sposobów opowiadania historii.

Zacznę od przybliżenia koncepcji Saldívara, który zauważa istotną zmianę w prozie etnicznej w USA na początku XXI wieku. Tą zmianą ma być pojawienie się prozy postrasowej jako reakcji na zmianę $\mathrm{w}$ definicji rasy, która przestaje być postrzegana w esencjalistyczny sposób jako kategoria biologiczna, a zaczyna się ją traktować jako zjawisko bardziej złożone. Rasa to element ludzkiego doświadczenia wynikający z charakterystyki przodków, ukształtowany przez wzorce społeczne i utrwalony przez instytucje w taki sposób, że dziś stanowi podstawę nierówności politycznych i ekonomicznych ${ }^{6}$. Tak rozumiana rasa nie jest cechą jednostkowej tożsamości, ale raczej skomplikowanym zbiorem czynów indywidualnych i społecznych. W tym miejscu Saldívar sięga do definicji rasy, którą sformułowały Paula M.L. Moya i Hazel Rose Markus, wskazującej na najważniejszy kontrast między propozycją Whiteheada i jego poprzednikami: rasa to „(...) a structure of doing, by which race is enacted and racial injustice perpetuated as 'social, historical and philosophical processes' (...) actions that people do"7. Rasa jest zatem działaniem.

Czytając Kolej podziemna, nie sposób zignorować faktu, że jest to powieść, która wykorzystuje historię czarnoskórych Amerykanów w zupełnie inny sposób niż jej poprzednicy. Whitehead nie dba o chronologię, chociaż wydarzenia opisywane w powieści mają charakter historyczny, ale przeplatane są wątkami fantastycznymi i nie ma mowy o tradycyjnej rekonstrukcji historii, jaką można zaobserwować u Faulknera czy Morrison. Ci, klasycy już literatury amerykańskiej, podobnie do Whiteheada nie byli zwolennikami narracji przyczynowo-skutkowej i linearnego

2 R. Saldivar, The Second Elevation of the Novel: Race, Form, and the Postrace Aesthetic in Contemporary Narrative, „Narrative” 2013, nr 21 (1), January, s. 1-18.

W. Faulkner, Świattość w sierpniu, przeł. M. Słomczyński, Czytelnik, Warszawa 1975.

4 S. Li, Genre Trouble and History's Miseries in Colson Whitehead's "Underground Railroad", „MELUS: Multi-Ethnic Literature of the U.S.” 2019, nr 44 (2), Summer, s. 1-23.

T. Morrison, Umiłowana, przeł. R. Gorczyńska, Społeczny Instytut Wydawniczy Znak, Kraków 2007. R. Saldivar, The Second Elevation of the Novel, op. cit., s. 2.

Ibidem (wyróżnienia oryg.). 
czasu, ale efekt zanurzenia $\mathrm{w}$ traumatycznej przeszłości Południa uzyskiwali między innymi przez dbałość o detale historyczne i konstruowanie różnych wariantów językowych, którymi posługiwali się ich bohaterowie w zależności od ich stopnia wykształcenia, miejsca pochodzenia i cech idiosynkratycznych. Temat rasizmu wybrzmiewa w Świattości w sierpniu i w Umiłowanej niezwykle poważnie, nie sposób też przeoczyć ewolucji w konstrukcji czarnych bohaterów. U Faulknera Joe Christmas jest niedookreślony i nigdy nie zostaje dopuszczony do głosu; nie możemy nawet być pewni, czy w jego żyłach płynie kropla czarnej krwi, która przypieczętowuje jego tragiczny los. Perspektywa opowiadania o czarnej Ameryce jest zewnętrzna i to głównie biali protagoniści, często zniewoleni przez swojej obsesje i zdegenerowani przez fanatyzm religijny i rasizm, są głównymi bohaterami Faulknera. U Morrison mamy perspektywę wewnętrzną, która umożliwia rewizjonistyczną etnohistoryczną podróż do piekła niewolnictwa i odsłania koszty tego systemu dla jego czarnych ofiar. Obraz przemocy w stosunku do Afroamerykanów jest tak samo przejmujący w obu powieściach; doznajemy podobnego wstrząsu, gdy obserwujemy lincz na Christmasie czy tortury niewolników w powieści Morrison.

Zanim zajmę się kwestią wykorzystania wątków historycznych u Whiteheada, chciałabym odnieść się do jednej z definicji afrofuturyzmu, która moim zdaniem wyjaśnia również dążenia autora Kolei podziemnej. Kodwo Eshun kontrastuje poetykę afrofuturystyczną z fantastyką naukową i dystopią, zauważając, że ta pierwsza daje bohaterom literackim możliwość interwencji i odzyskania kontroli ${ }^{8}$. Według Eshuna (z czym zapewne można polemizować, bo fantastyka naukowa i dystopia to kategorie bardzo szerokie i w ostatnich dekadach chętnie eksplorowane), teksty utrzymane w stylistyce sci-fi i postapokaliptyczno-dystopijnej szufladkują doświadczenie czarnych bohaterów, portretując ich miejsce pochodzenia - kontynent afrykański - jako przestrzeń zacofania i niedorozwoju. Afrofuturyzm natomiast pozwala na oddanie autonomii czarnym protagonistom i ratuje ich od zakleszczenia w przeszłości ${ }^{9}$. Afrofuturystyczna opowieść o czarnych niewolnikach sytuuje ich zamiast tego w centrum nowoczesności i w ten sposób pozwala im niejako poprawić historię przyszłości (,aims at correcting the history of the future") ${ }^{10}$. Słowami Eshuna, afrofuturyzm to program odzyskania historii (nie jednej, ale wielu!) w kontrprzyszłości, co jest szczególną misją w obliczu wrogości, z jaką mierzą się autorzy z diaspory afrykańskiej ${ }^{11}$. Mom zdaniem Colson Whitehead realizuje w swojej powieści bardzo podobny projekt, co postaram się wykazać w dalszej części artykułu, nie zapominając jednocześnie o tym, że żaden autor nie jest „samotną wyspą" i Whitehead kontynuuje w pewnym sensie dzieło swoich poprzedników, między innymi poprzez uzmysławianie

8 K. Eshun, Further Considerations of Afrofuturism, „The New Centennial Review” 2003, nr 3 (2), Summer, s. 291.

$9 \quad$ Ibidem, s. 292.

10 Ibidem, s. 298.

11 Ibidem, s. 300. 
czytelnikom za pomocą środków literackich, jak rasizm zmienia niektórych bohaterów w bestie i jak nieustannie powraca w rzeczywistości amerykańskiej.

Chociaż w powieści Whiteheada nie brakuje przerażających scen przemocy, jak u Faulknera i Morrison, można odnieść wrażenie, że dystans pomiędzy światem powieściowym a czytelnikiem jest znacznie głębszy i że prozaikowi nie zależało na takim zanurzeniu nas w historii, wprost przeciwnie - Whitehead celowo wydaje się odsłaniać granice pomiędzy fikcją literacką a rzeczywistością, a opowieść o Corze z Kolei podziemnej nie jest historią zrekonstruowaną, ale rodzajem gry z historią czy historią performatywną, jak nazywa ją Stephanie $\mathrm{Li}^{12}$. Żeby wyjaśnić ten termin, sięgnę w mojej analizie do niektórych wątków z jej artykułu. Li, która podobnie jak przywołani już przeze mnie badacze, twierdzi, że sposób wykorzystania wątków historycznych w powieści Whiteheada łączy się z nowoczesnym rozumieniem rasy jako działania i częściowo thumaczy wykorzystanie przez Whiteheada wątków fantastycznych, jak na przykład przekształcenia organizacji Kolej Podziemna w prawdziwy pociąg przemieszczający się przez imponującą sieć tuneli, który byłby cudem technologii w XIX wieku ${ }^{13}$. Według badaczki pomysł ten pozwala autorowi Kolei podziemnej na eksperymenty z czasem, czyli wprowadzenie strategii umiejscowienia przyszłości w przeszłości, typowej też dla afrofuturyzmu. Li zauważa, że ta zabawa czasem w powieści pozwala scalać przeszłość z teraźniejszością, pokazując nierozerwalny związek pomiędzy koszmarem XIX-wiecznego niewolnictwa, XX-wiecznej segregacji i współczesnego systemowego rasizmu. W przeciwieństwie do Faulknera, który zamykał swoich bohaterów w przeszłości, i Morrison, która zasugerowała sposoby przepracowania traumy jako ucieczki od koszmaru przeszłości, Whitehead nie zamierza chronologicznie przeprowadzać czytelnika od przeszłości do teraźniejszości, tylko oferuje mu postmodernistyczną grę z czasem, ponieważ tylko poprzez ten specyficzny performance może zrewidować stosunek Amerykanów do dziedzictwa historycznego. Afrofuturyzm w wydaniu Whiteheada stoi też w kontraście do celów prozy science fiction, która często utożsamiała przyszłość z postępem technologicznym, natomiast autor Kolei podziemnej projektuje posępną przyszłość, w której pomimo postępu technicznego brak jakiegokolwiek postępu moralnego - rasizm jest równie prymitywny, chociaż bardziej ukryty.

W zadaniu tym pomaga wykorzystanie ironii, której trudno szukać w przytoczonych powieściach Faulknera i Morrison. Whitehead wkracza na ryzykowny teren, wykorzystując subtelny czarny humor w opowieści o zbrodniczym systemie (np. w wątku o pracy Cory w charakterze żywego eksponatu muzealnego, do czego jeszcze powrócę), ale przyświeca mu szerszy cel. Saldívar zauważa, że pisarz ironicznie traktuje również termin ,,postrasa”, ponieważ dzięki ironii może wydobyć historyczne sprzeczności w spotykanej dzisiaj w USA tendencji usprawiedliwiania niesprawiedliwości rasowej lub ukrywania jej za pomocą sprytnie zmanipulowanych

12 S. Li, op. cit.

13 Ibidem. 
przekazów $^{14}$. Współczesny rasizm bywa nawet bardziej szkodliwy i niebezpieczny niż ten sprzed epoki uzyskania praw obywatelskich przez Afroamerykanów, ponieważ jest bardziej zawoalowany.

Tym ważniejsze staje się rozumienie roli historii i sposobów jej opowiadania. W jednym z wywiadów ${ }^{15}$ Whitehead stwierdza, że historia to opowieść fikcyjna skonstruowana przez społeczeństwo, z której niczego się nie uczymy, i dlatego koszmar cyklicznie powraca. Dobrze ilustruje to przekonanie Kolej podziemna, powieść o ucieczce czarnej niewolnicy Cory prawdziwym pociągiem, która wszędzie zderza się z koszmarem, bo nie może znaleźć Ameryki wolnej od rasizmu. Kolejne przystanki to inne warianty tej samej upiornej rzeczywistości, która wyklucza i prześladuje czarnych, często pod przykrywką nowoczesnych programów asymilacyjnych. Na przykład horror pracy na plantacji zostaje zamieniony w horror potencjalnej sterylizacji w ramach programów eugenicznych, które faktycznie funkcjonowały w USA. Konwencja powieści drogi sugeruje, że każde nowe miejsce przyniesie nadzieję i stworzy nowe możliwości, ale nigdy się tak nie dzieje. Można odnieść wrażenie, że Cora staje się ofiarą jakiegoś ponurego żartu, aktorką, która przymusowo odgrywa tę samą rolę przed otępiałą publicznością, której nie wzrusza żaden dramat i która nie reaguje na żadną scenę przemocy, bo od dawna się już przyzwyczaiła.

Wątek Ameryki jako sceny i Cory jako aktorki podejmuje Madhu Dubey w artykule Museumizing Slavery ${ }^{16}$. Warto w tym miejscu przytoczyć wnioski z tego opracowania na temat eksponowania niewolnictwa w muzeach amerykańskich stawiających na ,żywą historię” i związków pomiędzy technikami wystawienniczymi a literackimi strategiami Whiteheada. Dubey zwraca uwagę na pomysł pisarza, aby dosłownie potraktować niektóre motywy z historii Afroamerykanów. Najbardziej uderzającym przykładem jest wspomniany już przeze mnie wcześniej pomysł, aby Cora uciekała z plantacji nie z pomocą organizacji Kolej Podziemna, ale wykorzystując prawdziwy podziemny pociąg. Według badaczki ta strategia ma nam uświadomić, jak zmanipulowany jest dyskurs publiczny na temat tego wątku historycznego. Organizacja Kolej Podziemna stanowi we współczesnych Stanach Zjednoczonych popularny symbol współpracy pomiędzy rasami w pogoni za wolnością. Whitehead, zamieniając organizację na prawdziwy pociąg, dekonstruuje ten symbol, ponieważ przywraca sprawczość czarnym bohaterom. To oni zbudowali pociąg i skomplikowany system tuneli i to oni go kontrolują. Ponadto mit na temat Kolei Podziemnej uwypuklał znaczenie białych członków organizacji, którzy działali tylko na terenie północnych stanów, a w stanach południowych czarni zbiegli niewolnicy byli pozostawieni sami sobie ${ }^{17}$.

14 R. Saldivar, The Second Elevation of the Novel, op. cit.

15 T. Simpson, “The Underground Railroad” by Colson Whitehead (review), „Callaloo” 2017, nr 40 (2), Spring, s. 183-186.

16 M. Dubey, Museumizing Slavery: Living History in Colson Whitehead's "The Underground Railroad", „American Literary History” 2020, nr 32 (1), Spring, s. 111-139.

17 Kolejną ważną powieścią dekonstruującą mit Kolei Podziemnej i ikon abolicjonizmu, takich jak John Brown i Frederick Douglass, jest Ptak dobrego Boga Jamesa McBride'a. Zob. J. McBride, Ptak 
Kolejną zmianą w stosunku do mitu jest w powieści Whiteheada pokazanie takiego samego zniewolenia na wszystkich stacjach kolei - w powieści nie istnieje Ameryka zwracająca wolność. W micie na temat organizacji abolicjonistycznej podkreślone jest wspólne działanie, które przekształca zniewoloną przeszłość w wolną przyszłość. Whitehead robi w powieści wszystko, żeby uniknąć tego linearnego teleologicznego przekazu. Jak zauważa Dubey ${ }^{18}$, powieść obfituje w anachronizmy i spekulacje, które pomagają stworzyć asynchroniczny lub czasem multisynchroniczny portret alternatywnej Ameryki. W ten sposób Whitehead kwestionuje teleologię historii udowadniającą postęp w stosunkach rasowych. W końcu w jego powieści przemoc jest zapętlona w cyklicznym czasie ${ }^{19}$.

W tym miejscu Dubey zauważa pewną analogię pomiędzy Koleja podziemna a Umiłowana. W powieści Morrison duch też bez przerwy powraca, co pozwala autorce na podkreślenie kontinuum przeszłości i teraźniejszości. Celem Morrison, podobnie jak innych twórców neo-slave narrative, jest rekonstrukcja historii i skonfrontowanie czytelnika $\mathrm{z}$ tą historią, mające stanowić antidotum na publiczną amnezję. W większości podobnych powieści z tego nurtu ${ }^{20}$ ten zabieg wypada dobrze, ale problem pojawia się, gdy takie ,zanurzenie w historii” staje się dominującym trendem w amerykańskim muzealnictwie i niewolnictwo jest przez długi czas eksponowane zgodnie z metodologią żywej historii ${ }^{21}$. Dubey przypomina, że Colson Whitehead był krytyczny w stosunku do tej metody i konkluduje, że stanowisko pisarza mogło wpłynąć na skonstruowanie powieści jako szyderczej wersji zwiedzania w wersji spotkania z żywą historią. Co więcej, Whitehead z ironią podchodzi do wykorzystania historii $\mathrm{w}$ amerykańskich opowieściach o wyzwoleniu i postępie czarnych na drodze do emancypacji. W ten sposób autor Kolei podziemnej wyśmiewa interaktywną i głównie emocjonalną konsumpcję historii niewolnictwa ${ }^{22}$. Mnie interesuje też, w jakim stopniu Whitehead, odchodząc od strategii rekonstrukcji etnohistorycznej wypracowanej przez Morrison, w istocie dokonuje rewolucji w prozie etnicznej.

Warto w tym miejscu przyjrzeć się bliżej wspomnianym już wcześniej scenom z powieści, gdy Cora staje się ,żywym rekwizytem” w Muzeum Cudów Natury.

dobrego Boga, przeł. M. Świerkocki, Wydawnictwo Czarne, Wołowiec 2016.

Zob. A. Carpentier, Królestwo z tego świata, przeł. K. Wojciechowska, Wydawnictwo Literackie, Kraków 1986.

20 Również powieść Whiteheada jest do niego zaliczana.

${ }^{21}$ Metoda ta zyskała na popularności w ostatnich dekadach również w Europie. Miała być antidotum na wystawianie eksponatów wyłącznie w gablotach i pasywne zwiedzanie kolekcji opisywanych niedokładnie lub tylko za pomocą języka naukowego. Metoda żywej historii stawia na rekonstrukcję scen historycznych i interaktywne angażowanie zwiedzającego. Problem polega na selekcji scen i braku kontekstu historycznego. Moim zdaniem metoda dobrze sprawdza się w ekspozycjach dla dzieci, gdzie przekaz jest uproszczony i ważna jest komunikacja poprzez różne zmysły, bo młodsze dzieci nie potrafią czytać. 
Żeby zrozumieć analizę formalną powieści, należy uwzględnić kontrast pomiędzy zmanipulowaną ekspozycją niewolnictwa a wcześniejszymi przeżyciami bohaterki:

W sali „Typowy dzień na plantacji” Cora mogła usiąść przy kołowrotku i dać odpocząć stopom. Siedzisko było równie pewne jak jej stary klocek klonu cukrowego. Kury wypchane trocinami dziobały ziemię; raz po raz udawała, że rzuca im ziarna. Miała pewne podejrzenia, jeżeli chodzi o realizm scen w Afryce i na statku, ale w tym przypadku była ekspertką. Podzieliła się krytycznymi uwagami z panem Fieldsem. Przyznał, że kołowrotków rzadko używano na zewnątrz, przy wejściu do niewolniczej chaty, odparł jednak, że choć autentyczność to motto muzeum, rozmiary sali wymuszają pójście na pewne ustępstwa. Niestety nie zmieści na ekspozycji całego pola bawełny, a budżet nie pozwala na zatrudnienie tuzina aktorów, którzy na nim pracowali ${ }^{23}$.

Ten fragment pokazuje, jak współczesny jest język powieści i jak dobitnie wybrzmiewa ironia w takich opisach. Kilka stron dalej Whitehead doprecyzowuje zastrzeżenia Cory, gdyby niektórzy z czytelników zapomnieli, że Cora jeszcze jako dziewczynka doświadczyła na plantacji zbiorowego gwałtu i wielokrotnie przyglądała się przemocy. Dalej Cora komentuje ekspozycję dotyczącą warunków na plantacji:

Żaden niewolnik nie umarł z przepracowania nad kołowrotkiem ani nie został skatowany za splątanie nici. Nikt jednak nie chciał opowiadać o prawdziwej naturze świata. I nikt nie chciał o niej słuchać. Na pewno nie białe potwory znajdujące się w tej chwili po drugiej stronie szyby, przyciskające do niej śliskie ryje, pohukujące i szyderczo wykrzywiające gęby w uśmiechu. Prawda to zmieniająca się wystawa w sklepowej witrynie, przerabiana ręcznie, kiedy nie patrzysz - nęcąca i zawsze poza zasięgiem ${ }^{24}$.

Zestawienie takich scen to dobitna lekcja historii i komentarz na temat hipokryzji instytucji odpowiedzialnych za ochronę dziedzictwa pamięci. Zgadzam się z Dubey, że Whitehead napisał Kolej podziemna jako wyraz sprzeciwu przeciwko paternalistycznej estetyce, mającej długie tradycje w USA, wywodzącej się bezpośrednio z minstreli, zgodnie z którą niewolnicy to „happy darkies” - „szczęśliwe czarnuszki”25. Romantyczny obraz plantacyjnego niewolnictwa połączony z sugestią, że ostatecznie model ten otwierał drogę do awansu rasowego jest tu sparodiowany, ale szybko przestajemy się uśmiechać, bo w tej powieści muzeum łączy się ze szpitalem, a w szpitalu sterylizuje się czarne kobiety, okradając je z przyszłości. Jedyny sposób, w jaki Cora może się temu sprzeciwić, jest ucieczka, ale zanim to robi, pozwala sobie na zakłócanie dobrego samopoczucia zwiedzających. Według Dubey przejmuje wtedy na krótko kontrolę nad sytuacją i przestaje być jedynie obiektem. Jak wyjaśnia badaczka: „Cora's imaginary countermuseum marshals an aesthetic of the grotesque to recast US history as the stuff of nightmares" ${ }^{26}$.

\footnotetext{
23 Ibidem, s. 139.

24 Ibidem, s. 147.

25 Ibidem.

26 Ibidem, s. 117.
} 
Najciekawsze jednak w artykule Dubey jest pokazanie kontekstu historycznego, który umożliwił przekształcenie historii niewolnictwa w amerykańską opowieść o wolności. W latach 90. XX wieku Kongres USA zdecydował, że historia narodowa w USA musi zawierać zarówno wstydliwe, jak i inspirujące wątki. Chociaż sama ta decyzja wydaje się racjonalna (zwłaszcza w kontekście sporów w Polsce o historię żydowską i podejmowane przez niektóre środowiska prawicowe próby „wybielania" wątków uwzględniających antysemityzm), to stopniowo w USA publiczność zainteresowana turystyką dziedzictwa (heritage tourism) ${ }^{27}$ coraz częściej domagała się w muzeach historii wolnej od konfliktów. Nowe wystawy uwzględniały różnorodność (i to uśpiło czujność wielu krytyków), ale zazwyczaj przedstawiały niewolnictwo jako zaledwie fazę w historycznej narracji o postępie, która obowiązkowo kończyła się dojściem do wolności. Badacze tacy jak Dubey zwracają uwagę na współczesny systemowy rasizm, który nadal odbiera czarnym Amerykanom szanse na wolność. W mojej ocenie tych czynników ograniczających Afroamerykanów jest więcej, ale z braku miejsca mogę tylko zasygnalizować złożoność tej problematyki ${ }^{28}$, zgadzam się jednak, że jest to bardzo trafne spostrzeżenie w kontekście prozy Whiteheada. W momencie gdy niewolnictwo stało się kłopotliwym tematem, zastąpiono ten wątek historyczny opowieścią o Kolei Podziemnej. Historia tej organizacji, po odpowiednich przeróbkach, okazała się wzorem narracji o pojednaniu. Moim zdaniem przydała się również jako rodzaj kurtyny, która skutecznie przykryła Amerykę praktykującą prawa Jima Crowa.

Dubey zauważa ${ }^{29}$, że sama historia zmieniła się w grę dla turystów, bezrefleksyjną i uproszczoną, a empatię i identyfikację z niewolnikami wykorzystano jako narzędzie pedagogiczne. Skoro metoda żywej historii oparta jest na linearnej podróży w czasie, nie powinno nas dziwić, że Whitehead w swojej powieści inicjuje eksperymenty z czasem i dekonstruuje narodową narrację o wolności. W przeciwieństwie do Faulknera i Morrison, którzy za pomocą technik literackich konfrontowali czytelnika z horrorem rasizmu i niewolnictwa, próbując poprzez edukację przestrzec odbiorców przed konsekwencjami kontynuowania rasistowskich praktyk (w myśl przekonania, że wiedza o horrorze z przeszłości powstrzyma ludzi przed powtarzaniem tych samych błędów w przyszłości), Whitehead w swojej powieści stawia na jedną lekcję: w USA nie ma ucieczki od niewolnictwa. Dlatego w kontraście do tych twórców

27 Ibidem, s. 119.

${ }_{28}$ W artykule badaczki brakuje choćby wzmianki na temat różnorodności postaw wśród czarnoskórych Amerykanów; konflikty rasowe w USA nie przebiegają wyłącznie na linii biali kontra Afroamerykanie i nie można wszystkich problemów czarnej społeczności tłumaczyć i usprawiedliwiać systemowym rasizmem. Znakomicie ten temat podejmują prozaiczki i prozaicy, jak Zora Neale Hurston, Toni Morrison, Alice Walker czy James McBride, zwracający uwagę na współodpowiedzialność czarnych i białych Amerykanów za niektóre procesy oraz zjawiska. Problematyka rasy i konfliktów społecznych w USA doskonale została też prześwietlona w serialu The Wire Davida Simona, który jest najpełniejszą analizą filmową tych zjawisk, unikającą zarówno idealizacji, jak i demonizacji czarnych i białych bohaterów. 
(literackich i z innych dziedzin sztuki), którzy zakładają, że emocjonalne zanurzenie w traumatycznej przeszłości może skutkować transformacją psychologiczną, autor Kolei podziemnej wprowadza wspomniany już dystans pomiędzy czytelnikiem a historią.

W podsumowaniu Dubey doprecyzowuje też kwestie gatunkowe, nazywając, za innymi krytykami ${ }^{30}$, powieść satyrą spekulatywną (speculative satire). Już przy lekturze powieści zwróciłam uwagę na odwołania do Jonathana Swifta, stąd też kwestia gatunku wydaje mi się na tyle istotna, że na moment się przy niej zatrzymam. Według badaczki Whitehead nie wierzy, że katharsis przeżywane w zetknięciu z historią niewolnictwa ma potencjał transformacji i zmienia odbiorców ${ }^{31}$. Autor Kolei podziemnej zmienia zatem strategię stosowaną przez prozaików z nurtu neo-slave narrative ${ }^{32}$ i zamiast wypełniać luki w historii (w końcu historie grup etnicznych często stanowią kontrhistorie w stosunku do historii narodowej w USA i często nie są tak dobrze znane), Whitehead reaguje na nadmiar reprezentacji.

Moim zdaniem przede wszystkim interesuje go hipokryzja i zmanipulowany obraz historii, która okazała się zbyt niewygodna. W przeciwieństwie do Dubey nie uważam, że największym problemem jest pewna moda na opowieści zanurzające odbiorców w historii czy marketingowe wykorzystanie historii niewolnictwa. Dla mnie zasadniczą kwestią jest przejęcie pewnego sposobu opowiadania o historii w nieuczciwych celach. Chociaż dzisiaj ocena Faulknera jako pisarza piętnującego rasizm jest różna (broniąc integralności Południa niewystarczająco przyjrzał się kwestiom niewolnictwa), Świattość $w$ sierpniu to powieść, która bardzo krytycznie pokazuje konsekwencje rasizmu i niewolnictwa właśnie i na pewno nie wpisuje się w zakłamaną opowieść o niewolnictwie jako zaledwie fazie w świetlanej historii USA. Podobnie Umiłowana Morrison (ale też wiele innych powieści z jej dorobku, jak chociażby Pieśń Salomonowa czy Odruch serca ${ }^{33}$ ) nie sugeruje, że niewolnictwo i jego konsekwencje to „pieśń przeszłości”. Brak też u Faulknera i Morrison naiwności wystaw muzealnych opisywanych przez Dubey, które bardzo powierzchownie traktują wątki historyczne i maskują choroby toczące USA. Faulkner i Morrison stawiają moim zdaniem bardzo podobną diagnozę; rasizm to nieuleczalna choroba trawiąca

30 Zob. np. R. Saldívar, Historical Fantasy, Speculative Realism, and Postrace Aesthetics in Contemporary American Fiction, „American Literary History” 2011, nr 23 (3), s. 574-599; M. Dischinger, States of Possibility in Colson Whitehead's “The Underground Railroad”, „The Global South” 2017, nr 11 (1), Spring, s. 82-89.

31 M. Dubey, Museumizing Slavery, op. cit.

32 Warto zauważyć, że jest to strategia często wykorzystywana przez wielu pisarzy nie tylko z mniejszości etnicznych i często mamy do czynienia z różnymi wariantami powieści historycznej, które w przeciwieństwie do XIX-wiecznej protoplastki wykorzystują techniki modernistyczne i postmodernistyczne. Więcej zob. A. Gondor-Wiercioch, Pomiędzy rekonstrukcja a mitem. Role historii we wspótczesnej prosie rdzennych Amerykanów i Latino/a, Księgarnia Akademicka, Kraków 2016.

33 Wydania polskie zob. T. Morrison, Pieśn Salomonowa, przeł. Z. Uhrynowska-Hanasz, Świat Książki, Warszawa 2015; eadem, Odruch serca, przeł. M. Olejniczak-Skarsgård, Wydawnictwo „Albatros” Andrzej Kuryłowicz, Warszawa 2009. 
społeczeństwo amerykańskie i daleka jest droga do jego eliminacji, a leczenie samych symptomów na nic się zdaje (w przypadku wystaw muzealnych krytykowanych przez Dubey to nawet nie jest leczenie symptomów, tylko maskowanie terapii).

Na koniec chciałabym jeszcze odnieść się do samej formy powieści Whiteheada. Konstatując, że nie dostrzegam specjalnej różnicy w przesłaniu pomiędzy Świattościa w sierpniu i Umilowanq a Koleja podziemna, zgadzam się, że na poziomie treści powieść Whiteheada jest rewolucyjna, jak pokazują badacze skoncentrowani na nowatorstwie formalnym. Dla mnie to o tyle przełomowa powieść, że bardzo kreatywnie przetwarza wątki afrofuturystyczne, które w kulturze masowej często bywają spłycone. Bliska jest mi opinia Saldívara, który pisząc o prozie postrasowej, zauważa, że zaletę najlepszych pisarzy etnicznych stanowi właśnie umiejętność inteligentnego przekształcenia pewnych strategii postmodernistycznych, czyli łączenie kultury wysokiej i popularnej oraz mieszania różnych gatunków i konwencji, również tych z pogranicza kiczu. Temat ten podejmuje również Li, która przytacza definicję spekulatywnego realizmu autorstwa Saldívara i, co ciekawe, odnosi się do kwestii formalnych w Umiłowanej Morrison, warto więc prześledzić ewolucję neo-slave narrative na tych przykładach. Dodatkowo, sięgając do interpretacji Li, mogę powrócić do wątku historii performatywnej, od którego zaczęłam artykuł i który warto doprecyzować.

Realizm spekulatywny, będący szerszą kategorią niż satyra spekulatywna i świadczący o pewnej ewolucji prozy afrofuturystycznej, jest bardzo eklektyczny. Saldívar, cytowany przez Li, podaje, że jest to: ,a hybrid amalgam of realism, magical realism, metafiction, and genre fictions, including science fiction, graphic narrative, and fantasy proper" ${ }^{\prime 4}$. Ta poetyka łączy się z postulatami prozy postrasowej, ponieważ w obu przypadkach twórcy wykorzystują elementy neofantastyki, nie w celu eksploracji sennych wizji czy majaków, ale w celu badania historii i sposobów jej przetwarzania $^{35}$. Według Li to nowe zastosowanie elementów fantastycznych służy wyeksponowaniu prawdy historycznej, zatem jest to kontynuacja celów, jakie stawiał sobie realizm historyczny. Whitehead w dużo większym stopniu miesza gatunki. Ja dodałabym też, że aktywizuje czytelnika w inny sposób niż Faulkner czy Morrison. $\mathrm{W}$ ich powieściach narracja polifoniczna i odejście od czasu linearnego wymagały od czytelnika złożenia fragmentarycznych świadectw w jedną spójną historię. W obu przypadkach za osiągnięcie literackie uważa się sposób rekonstruowania wielowątkowej historii.

Li uważa, że Whitehead nie jest zainteresowany odtworzeniem historii, ale traktuje historię jako grę. Pomimo różnicy w podejściu do historii badaczka zwraca uwagę na pewne podobieństwo pomiędzy Umiłowana i Koleja podziemna. Obie powieści bardziej zainteresowane są kwestią prawdy niż faktami. Tak jak Morrison powołała się na historię Margaret Garner, ale była to zaledwie luźna inspiracja i wątek Sethe różnił się znacznie od oryginalnej historii, tak też Whitehead wykorzystuje

34 S. Li, op. cit., s. 1, za: R. Saldívar, The Second Elevation of the Novel, op. cit., s. 13.

35 Ibidem. 
prawdziwe fakty z historii Afroamerykanów, ale w fikcyjnej kolejności. Jaką prawdę zatem odsłaniają? U Morrison mamy próbę oddania prawdy psychologicznej (cierpienia dzieciobójczyni zestawione z szerszą traumą niewolnictwa), a u Whiteheada eskapizm, który zamiast konfrontować czytelnika z historią, „drażni go przemocą"36 podczas podróży fantastycznym, nigdy nieistniejącym pociągiem. Autor Kolei podziemnej nie stosuje rekonstrukcji historycznej, ale historyczny performans po to, żeby zaspokoić oczekiwania czytelników liczących na powieść historyczną. Dzięki historii performatywnej Whitehead odsłania sztuczność tekstu literackiego.

Li zauważa też, że podobnie jak Umiłowana wymaga od czytelnika uznania roszczeń ducha (którego doświadczenie tak naprawdę łączy się z traumą innych ofiar niewolnictwa, więc chodzi o zbiorowe cierpienie czarnych Amerykanów wyparte $\mathrm{z}$ narodowej historii), tak Kolej podziemna wymusza na czytelniku zauważenie śladów niewolniczej historii we współczesnej Ameryce ${ }^{37}$. Badaczka dodaje też, że chociaż sam Whitehead twierdził, iż jego utwór nie jest powieścią historyczną, jest to tekst świadczący o głębokim zainteresowaniu historią. Li wraca też do podobieństwa pomiędzy Morrison i Whiteheadem polegającego na przywiązaniu do prawdy, a nie do faktów. Umiłowana została przez autorkę pomyślana jako swoisty suplement do tekstów historycznych i kluczowe stało się rozróżnienie pomiędzy faktami a prawdą, ponieważ Morrison doszła do wniosku, że fakty historyczne są mniej ważne niż projekt precyzyjnie opisujący wpływ przemocy i zinstytucjonalizowanej dehumanizacji na ludzką psychikę.

Li konkluduje, że w Kolei podziemnej realizm spekulatywny nie służy podważeniu realizmu historycznego i, podobnie jak inni badacze i badaczki, zgadza się, że Whitehead nie edukuje czytelników na temat historii, ale uzmysławia im, jak wiele zależy od sposobów jej traktowania: „Whitehead is caught in history that exceeds his own imagination. (...) He is acutely aware that history often operates as a performance, constructed by those with power to tell or compose a story"38. Li zgadza się też z omawianym już wątkiem dekonstrukcji Kolei Podziemnej jako narodowego mitu i w kwestii oceny ekspozycji muzealnych poświęconych niewolnictwu jest nawet bardziej sceptyczna od Dubey, bo nie tyle widzi problem w zastosowaniu metody żywej historii, ile dochodzi do wniosku, że żadne muzeum nie jest w stanie przekazać doświadczenia niewolnictwa ${ }^{39}$. Na koniec Li zauważa, że pomimo postmodernistycznej techniki Whitehead decyduje się na konwencjonalne zakończenie typowe

36 S. Li, op. cit., s. 5.

37 Ibidem, s. 7.

38 Ibidem, s. 11.

39 Z tym zapewne można polemizować - wydaje mi się, że muzea w obozach koncentracyjnych są najbliżej oddania doświadczenia horroru ludobójstwa, ale na jednej z konferencji spotkałam prelegentkę, która opowiadała o greckim projekcie czytania dokumentów i literatury oraz oglądania filmów na temat Holokaustu. Projekt zakończył się wizytą w Muzeum Auschwitz. Prowadząca projekt odnotowała, że młodzież nie była specjalnie poruszona tym miejscem i o wiele bardziej przeżywała książki i filmy na temat Zagłady, więc są to najprawdopodobniej kwestie indywidualne. 
dla slave narrative - Cora staje przed szansą na wolność, całościowo jednak powieść ma wydźwięk pesymistyczny, bo jest opowieścią o ogromnym cierpieniu.

Zanim przejdę do podsumowania omówionych tu wątków, zatrzymam się na chwilę na ekranizacji serialu autorstwa Barry'ego Jenkinsa z roku 2021, ponieważ niewątpliwie odsyła ona widzów do jeszcze innej perspektywy interpretacyjnej. Jenkins znany jest głównie jako autor filmów Moonlight, który oceniam jako bardzo udany, i Gdyby ulica Beale mogła mówić; ten obraz z kolei wspominam jako dość nużący. Niestety wrażenie znudzenia towarzyszyło mi również w trakcie oglądania Kolei podziemnej, co jest o tyle zaskakujące, że to zazwyczaj powieści wymagają od czytelnika większej uwagi i sprawiają trudności w odbiorze, zatem wcale mnie nie dziwi fakt, że uczniowie i studenci chętniej wybierają ekranizacje. Powieść Whiteheada czytałam kilka razy i za każdym razem była to wciągająca lektura ze względu na precyzyjny język, szybkie tempo i zaskakujące zwroty akcji. Oglądając serial, można zaś odnieść wrażenie, że został oparty na prozie rozbudowanej przez niezliczone opisy i pozbawionej zupełnie akcji. Jednocześnie muszę przyznać, że zauroczyły mnie znakomite zdjęcia Jamesa Laxtona oraz świetna gra Thuso Mbedu (Cora), natomiast brak tempa i pewna powtarzalność efektów (specyficzne światło, wykorzystanie mgły, powtórzenia podobnych scen) wywołują wrażenie, że ważniejsze są efekty artystyczne (połączenie serii doskonale skomponowanych ,żywych obrazów”) niż umiejętność sprawnego opowiadania fabuły. Zastanawiam się też, dlaczego twórcy ekranizacji nie zdecydowali się na film zamiast serialu; Umiłowana Toni Morrison (powieść podobnej długości do Kolei podziemnej Whiteheada) doczekała się przecież o wiele ciekawszej i zwartej ekranizacji autorstwa Jonathana Demme'a ${ }^{40}$.

Dopracowanie scenografii i kostiumów z jednej strony zasługuje na uznanie, ale z drugiej zamyka opowieść w przeszłości i trudno u Barry’ego Jenkinsa znaleźć jakieś elementy afrofuturystyczne; serial jest głównie realistyczny, a współczesny wydźwięk pewnych wątków mają podkreślać utwory muzyczne na koniec odcinków i obraz drapacza chmur czy sama kolej jako pojazd. Wydaje mi się, że dużo lepszym pomysłem byłoby zróżnicowanie całej ścieżki dźwiękowej, która mogłaby „przenosić" widza w czasie i wzbudzać niepokój, zaburzając czas historyczny. Taki zabieg znakomicie udał się Stevenowi Soderberghowi w serialu The Knick, gdzie realistyczna opowieść o historycznym szpitalu nowojorskim jest wzbogacona o muzykę elektroniczną i techno, co pozwala na konstruowanie analogii między przełomem XIX i XX wieku a naszymi czasami, ilustrującej założenie, że pomimo postępu technologicznego ludzkie ambicje, lęki i obsesje nie zmieniają się. Jest to o tyle stracona okazja, że - jak, mam nadzieję, udało mi się wykazać w artykule - kwestia multisynchronizmu jest bardzo ważna w powieści Whiteheada i pisarz zrobił wszystko, żeby pokazać żywotność rasizmu i nie zamykać go w tradycyjnej opowieści o przeszłości.

Kolejnymi elementami wpływającymi na negatywne wrażenia są pewien patos i moralizatorstwo ekranizacji, których trudno szukać w samej powieści. Z jednej

40 Niestety z kuriozalnym polskim tytułem Pokochać. 
strony wpływ na to ma budowanie opowieści poprzez serię poetyckich symbolicznych obrazów mających podkreślać niekończącą się przemoc oprawców i desperację ofiar, z drugiej - w powieści ta perspektywa podszyta jest subtelną ironią i momentami czarnym humorem. Warto w tym miejscu przypomnieć, że krytycy nazwali powieść satyrą spekulatywną oraz że Whitehead wielokrotnie odnosi się do innej słynnej satyry, a mianowicie Podróży Guliwera Jonathana Swifta, więc czarny humor jest istotnym komponentem.

W ekranizacji dochodzi też do pewnego uproszczenia charakteryzacji bohaterów: czarni są heroiczni i humanitarni z wyjątkiem Homera (dziecka zdemoralizowanego przez białych), a biali słabi, tchórzliwi i prymitywni. Żeby wydobyć tę dychotomię, twórcy serialu wprowadzają nawet dodatkowe, nieobecne w powieści wątki, jak na przykład spalenie całej miejscowości w akcie zemsty za ukrywanie Cory czy przesadne rozbudowanie wątków Ridgewaya, który w powieści jest jednym z wielu prymitywnych białych rasistów, a w serialu staje się demoniczną postacią przypominającą ikoniczne czarne charaktery, jak na przykład kapitan Ahab z Moby Dicka Hermana Melville'a czy Kurtz z Jądra ciemności Josepha Conrada. Jest to dla mnie zabieg niezrozumiały i zmieniający wydźwięk powieści, po pierwsze dlatego, że przesuwa kwestię odpowiedzialności za rasizm ze zbiorowości na jednostkę, co może sugerować, że tylko wyjątkowo zdeprawowane jednostki wpłynęły na kształt historii niewolnictwa w USA, a zwykli ludzie w tym nie uczestniczyli, co oczywiście jest nieprawdą i powieść Whiteheada zawiera mnóstwo kontrargumentów uniemożliwiających taką interpretację. Po drugie, jednym z największych osiągnięć powieściopisarzy i twórców filmowych jest pokazywanie skomplikowanej rzeczywistości w spolaryzowanym współczesnym świecie, w którym ogromną popularnością cieszą się uproszczone i nieprawdziwe opowieści. Powieść Whiteheada rzuca nowe światło na sposoby konstruowania i zawłaszczania dyskursu historycznego, gdzie opowieść o historii i negocjacji jej sensu jest przez autora celowo komplikowana, co z kolei zmusza nas do myślenia i zachęca do zerwania z utartymi schematami wynikającymi z bezmyślnej konsumpcji tekstów kultury. Oryginalna Kolej podziemna jest też opowieścią zwracającą autonomię czarnym bohaterom i bohaterkom, dlatego kluczowe są proporcje pomiędzy narracjami. W ekranizacji Jenkinsa opowieść Cory na długo staje się opowieścią Ridgewaya i nawet jeżeli chodziło o przyciągnięcie przed ekrany również białej publiczności, to poświęcenie aż takiej uwagi jednej patologicznej białej postaci wydaje się nieuzasadnione.

Podsumowując, muszę się zgodzić z postulatami Sadívara, Dubey i Li, że Kolej podziemna jest przełomową propozycją pod kątem połączenia nowatorskich strategii literackich z przesłaniem. To ostatnie jednak nie wydaje mi się aż tak rewolucyjne i zrywające z przekonaniami takich poprzedników i poprzedniczek literackich, jak William Faulkner i Toni Morrison. Centralnym tematem Światłości w sierpniu, Umiłowanej i Kolei podziemnej jest rozrachunek z rasizmem w kontekście historii narodowej USA i pomimo kontrastów formalnych nikt $z$ autorów i autorek nie zdecydował się na sugestię, że niewolnictwo to zaledwie epizod w historii USA i jego 
konsekwencje zostały już przepracowane. W każdej propozycji niewolnictwo oraz jego skutki powracają jako niekończąca się historia; w Światłości w sierpniu ani prostoduszni mieszkańcy Południa, ani lepiej wykształceni abolicjoniści nie są w stanie powstrzymać zdegenerowanych rasistów od linczu na Christmasie i jest oczywiste, że to pomieszanie bezsilności z okrucieństwem stanowi stałą cechę krajobrazu Południa. W Umiłowanej udaje się wypędzić ducha i uratować Denver, ale nikt i nic nie jest w stanie zakończyć żałoby Sethe, a w Kolei podziemnej Cora dzięki technice multisynchronizmu żyje jednocześnie w przeszłości i przyszłości, czyli naszym czasie teraźniejszym, więc w żadnej mierze nie można odnieść wrażenia, że Whitehead lokuje horror niewolnictwa w zamkniętej przeszłości. Powieść kończy się, gdy Cora wciąż jest w trakcie podróży, wciąż musi być czujna i musi myśleć samodzielnie, bo w otaczającej rzeczywistości czyha na nią mnóstwo pułapek. To dość analogiczna sytuacja do rzeczywistości czytelnika, który we współczesnym świecie, gdzie dostęp do informacji jest nieporównanie większy i łatwiejszy niż w przeszłości, nadal nie powinien sobie pozwalać na pasywizm i bezrefleksyjne dziedziczenie tradycji historycznej.

\section{Bibliografia}

Carpentier A., Królestwo z tego świata, przeł. K. Wojciechowska, Wydawnictwo Literackie, Kraków 1986.

Dischinger M., States of Possibility in Colson Whitehead's "The Underground Railroad", „The Global South” 2017, nr 11 (1), Spring, s. 82-89.

Dubey M., Museumazing Slavery: Living History in Colson Whitehead's "The Underground Railroad”, „American Literary History” 2020, nr 32 (1), Spring, s. 111-139.

Eshun K., Further Considerations of Afrofuturism, „The New Centennial Review” 2003, nr 3 (2), Summer, s. 287-302.

Faulkner W., Światłość w sierpniu, przeł. M. Słomczyński, Czytelnik, Warszawa 1975.

Gondor-Wiercioch A., Pomiędzy rekonstrukcją a mitem. Role historii we współczesnej prozie rdzennych Amerykanów i Latino/a, Księgarnia Akademicka, Kraków 2016.

Li S., Genre Trouble and History's Miseries in Colson Whitehead's "Underground Railroad”, „MELUS: Multi-Ethnic Literature of the U.S.” 2019, nr 44 (2), Summer, s. 1-23.

McBride J., Ptak dobrego Boga, przeł. M. Świerkocki, Wydawnictwo Czarne, Wołowiec 2016.

Morrison T., Odruch serca, przeł. M. Olejniczak-Skarsgård, Wydawnictwo „Albatros” Andrzej Kuryłowicz, Warszawa 2009.

Morrison T., Pieśń Salomonowa, przeł. Z. Uhrynowska-Hanasz, Świat Książki, Warszawa 2015.

Morrison T., Umiłowana, przeł. R. Gorczyńska, Społeczny Instytut Wydawniczy Znak, Kraków 2007.

Saldívar R., Historical Fantasy, Speculative Realism, and Postrace Aesthetics in Contemporary American Fiction, „American Literary History” 2011, nr 23 (3), s. 574-599.

Saldivar R., The Second Elevation of the Novel: Race, Form, and the Postrace Aesthetic in Contemporary Narrative, „Narrative” 2013, nr 21 (1), January, s. 1-18. 
Simpson T., “The Underground Railroad” by Colson Whitehead (review), „Callaloo” 2017, nr 40 (2), Spring, s. 183-186.

Whitehead C., Kolej podziemna. Czarna krew Ameryki, przeł. R. Lisowski, Albatros, Poznań 2017. 